\title{
Južnoitalsko učenje o duši
}

\author{
1 Željko Kaluđerović \\ 1 Odsjek za filozofiju, Filozofski fakultet Sveučilišta u \\ Novom Sadu, Novi Sad, Srbija
}

Sažetak: U radu se istražuju posredno i neposredno sačuvani stavovi Pitagore i pitagorejaca koji, po autorovu mišljenju, predstavljaju ishodišnu točku odstupanja od glavnog toka zapadne filozofije i anticipiraju većinu kasnijih modaliteta neantropocentričnih pristupa. Fragmenti italskih mislilaca, drugačije rečeno, mogu poslužiti gotovo kao smjernice danas tako aktualnim (bio) etičkim zahtjevima za novim i drugačijim rješavanjem relacije između ljudi i tzv. neljudskih živih bića. Pitagorejska ideja da su svi oblici života srodni nije samo dovela u vezu ljude sa životinjama i biljkama nego i nagovijestila da ljudska duša, doduše tek nakon pročišćenja, može postići stapanje $s$ vječnom i božanskom dušom, kojoj po svojoj prirodi i pripada. Na vezu i analogiju koja se može uspostaviti između čovjeka i univerzuma upućuje Aristotelova konstatacija kako je prema pitagorejcima moguće da bilo koja duša uđe u bilo koje tijelo. Ovo srodstvo svih varijeteta života bila je nužna pretpostavka pitagorejskog učenja o besmrtnosti i seobi duša. O palingenesiji izvještava Ksenofan poznatim riječima da je Pitagora u prolazu vidio kako neki ljudi tuku psa pa im je rekao da to više ne rade, jer je po jaukanju životinje prepoznao da je to duša njegova prijatelja. Iz 7 . fragmenta Kolofonjanina vidljivo je zašto srodstvo svih bića koje je u vezi s učenjem o seobi duša stoji u osnovi pitagorejske zabrane jedenja životinjskog mesa. Pitagorino prepoznavanje duše prijatelja utjelovljene u psu ilustrira i prenošenje osobnog identiteta na psyche, što znači da osobnost na neki način preživljava u selidbama duše i da postoji kontinuitet identiteta. Zaključak je koji se može izvesti, barem implicitno, da su oduhovljena bića, dakle, i životinje, ali i neke biljke, u određenom smislu svjesna bića.

Ključne riječi: Pitagora i pitagorejci, neantropocentrizam, srodnost, život, duša, učenje, besmrtnost, palingenesia

Datum primitka: 22.05.2017.

Datum prihvaćanja: 10.06.2017.

DOI: $10.24141 / 3 / 1 / 2$

Adresa za dopisivanje:

Željko Kaluđerović

Odsjek za filozofiju, Filozofski fakultet Sveučilišta u Novom Sadu dr. Zorana Đinđića 2, 21000 Novi Sad, Srbija

E-pošta: zeljko.kaludjerovic@ff.uns.ac.rs

Tel: +381 214853900 
Jedna je od univerzalno poznatih i priznatih činjenica povezanih s Pitagorom da je prvi donio u Grčku učenja da je sve živo što se rađa međusobno srodno. Ideja da su svi oblici života srodni nije samo dovela u vezu ljude sa životinjama i biljkama nego i nagovijestila da ljudska duša, doduše tek nakon pročišćenja, može postići stapanje s vječnom i božanskom dušom, kojoj po svojoj prirodi i pripada. Ovo srodstvo svih varijeteta života bila je nužna pretpostavka pitagorejskog učenja o seobi du-

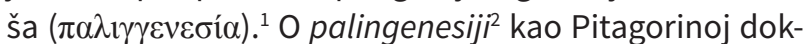
trini izvještava Ksenofan poznatim riječima (DK21B7) $]$ žanski i prirodni razlozi"? Aristotel je u izgubljenom spisu $O$ pitagorejcima (DL, VIII, 34), napisao da je Pitagora savjetovao da se ne jede bob i zbog njegove sličnosti sa „stidnim dijelovima tijela” ili s vratima Hada. Bob se jedini nigdje ne sastavlja ili zato što je štetan ili zato što je po obliku sličan cijelom svemiru. Bob i nadima i tako ima najviše veze s duševnim dijelom, štoviše, sadrži duše mrtvih, a istovremeno nosi porijeklo, kao i ljudska bića, iz istog oblika prvobitne tvari. Svim spomenutim tumačenjima, a i nekim drugima, povremeno bizarnima, zajedničko je to da je uspostavljena veza između boba

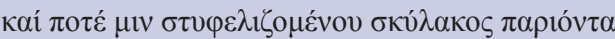

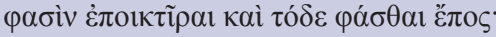

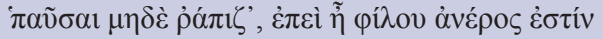

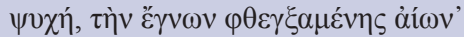

Iz ovog fragmenta vidljivo je zašto srodstvo svih bića koje je u vezi sa učenjem o seobi duša stoji u osnovi zabrane jedenja životinjskog mesa od strane, barem nekih, pitagorejaca. Ovaj fragment pokazuje i da je pitagorejsko vjerovanje u preporod ili obnavljanje duše već u šestom stoljeću prije naše ere bilo dovoljno dobro poznato da bi moglo biti parodirano. Pitagorino prepoznavanje duše prijatelja utjelovljene u psu ilustrira, s druge strane, prenošenje osobnog identiteta na $\psi v \chi \eta ́$, što znači da osobnost na neki način preživljava u selidbama duše i da postoji kontinuitet identiteta. ${ }^{4}$ Zaključak je koji se može izvesti, barem implicitno, da su oduhovljena bića, dakle, i životinje, ali i neke biljke, u određenom smislu svjesna bića.

Strukturni je problem ovakvog gledišta kako uklopiti srodnost cjelokupne physis s logičkim implikacijama da onda ni biljke ne treba konzumirati, s obzirom na to da su, prema pitagorejcima, živa bića i dio zajedništva prirode. U bilješkama Aleksandra Polihistora (DL, VIII, 28) spominje se da je u Pitagorejskim uspomenama pronašao rješenje paradoksa. Pitagorejci su smatrali da živi sve što sudjeluje u toplini, to je i razlog zašto su biljke živa bića ( $\zeta \tilde{\omega} \alpha)$, ali da sve nema dušu ( $\psi v \chi \eta ̀ v)$. Duša je otrgnuti komadić aithera („neograničenog daha“, tj. tzv. petog elementa), onog toplog i onog hladnog. Duša se razlikuje od života, besmrtna je ${ }^{5}$ jer je besmrtno i ono od čega se odvojila. ${ }^{6}$ Biljke, znači, posjeduju život, ali nemaju sve dušu pa su neke od njih pogodne za konzumiranje.

Moguće je da razlog zašto su se pitagorejci suzdržavali od jedenja boba (lat. Vicia faba) ${ }^{7}$ leži u činjenici da su vjerovali u njegovu oduhovljenost. Jamblih kao motiv zašto je Pitagora propisivao da se ne jede bob dodaje i „mnoge božanske i prirodne razloge”. 8 Koji su to „bo- i života, smrti i duše. Misteriozno utjelovljenje univerzalnoga životnog daha i bliska veza s ljudskim životom koje su pitagorejci vidjeli u bobu dovela je do toga da ga zabrane za jelo.

Usporedbom vjerovanja u palingenesiju ${ }^{9}$ i homogenost (ó nih plemena uočava se da i kod određenih „divljih“ plemena vjerovanje u srodnost svih živih bića ide zajedno s kontingentom zabrana tj. tabua. Ove zabrane vrlo se često odnose na to što se ne smije jesti, premda se mogu odnositi i na druge stvari koje iz današnje perspektive nemaju baš mnogo smisla. Razlika je između ovih plemena i pitagorejske zajednice to što kod spomenutih plemena tabui imaju karakter puke zabrane, bez objašnjenja njihova značenja i smisla. Kod pitagorejaca, barem nekih, s druge strane, propisi o suzdržavanju od određenih vrsta hrane bili su doktrinarno utemeljeni, osmišljeni odnosno obrazloženi. ${ }^{10}$ Ako, recimo, nije dopušteno hraniti se životinjskim mesom, onda takva zabrana proizlazi iz rizika da se jedu dalji ili bliži rođaci. ${ }^{11}$ Drugačije rečeno, kada se jede životinjsko meso, čovjek se izlaže opasnosti da pojede nekog svojeg pretka čija se duša u kontinuiranim selidbama uselila u tijelo, naprimjer, nekog janjeta.

Brojna su i heterogena svjedočanstva o ovoj temi, koja, kao i neke druga pitanja koja su razmatrana u pitagorejskom bratstvu, izazivaju kontroverze. Njih same vrlo je teško sistematiziramo i konsekventno interpretirati, pa ne čudi što stavovi oko (ne)upotrebe životinjskog mesa nisu u potonjim vremenima jednoznačno prihvaćani. Ukratko, varirali su od uvjerenja o potpunoj zabrani upotrebe mesa životinja u bratstvu, preko suz- 
državanja od jedenja samo određenih vrsta životinja, do kategoričkog poricanja bilo kakve zabrane konzumiranja mesa.

Prema prvoj verziji, Pitagora nije dozvoljavao da se jede meso životinja, a razlog je dobro poznat - one „kao mi (ljudi, op. Ž. Kaluđerović) imaju dušu“ (DL, VIII, 13). U nastavku ovog pasusa, istina, navodi se da je bitna srodnost životinja i ljudi bila svojevrsna kamuflaža i maska filozofa sa Samosa. Njegova tobože „istinska“ namjera bila je da zabranom mesa životinja za ishranu postigne umjerenost $\mathrm{u}$ ishrani kod ljudi i lakše nabavljanje same hrane. To je prema ovoj interpretaciji bio put ka dobrom tjelesnom zdravlju i bistrini duše. On ne samo da se suzdržavao od životinjske hrane nego je, po Eudoksu, zbog svojeg zgražavanja nad ubijanjem i ubojicama općenito išao toliko daleko da je čak odbijao družiti se s kuharima i lovcima.

Smatralo se zatim da su neke životinje svete i da ako se jedu, mogu narušiti bliskost bogova i ljudi. Zato je u bratstvu bilo zabranjeno jesti bijele pijetlove, jer su posvećeni Mjesecu, a posvećeni su Mjesecu jer oglašavaju vrijeme dana, kao što se nisu smjele dirati ni svete ribe, odnosno crnorepke i crvenorepke koje su bile posvećene zemaljskim bogovima. Jamblih pak bilježi da se, prema pitagorejskim acusmatama, smiju konzumirati samo životinje koje su prikladne za žrtvovanje, s obzirom na to da samo u njih ne ulazi ljudska duša. Ova zbirka pravila pitagorejskog načina života donosi i zabranu jedenja životinjskog srca, možda zato što se pretpostavljalo da je baš u njemu smještena duša. Porfirije u popisu Pitagorinih Symbola navodi da se od dijelova žrtvovanih životinja ne smiju jesti ni slabine, testisi, spolni organi, moždina, noge ni glava, zbog njihova simboličkog značenja. Oni su na životinjama istovremeno označavali začeće, rađanje, rast, početak i kraj; u cjelini gledano, predstavljali su vodeće dijelove tijela.

Od Aristoksena pa nadalje bilo je odlučnih pokušaja i da se u osnovi negira postojanje zabrane. Aristoksen, suprotno prethodnim tvrdnjama, smatra da je bob bilo Pitagorino omiljeno povrće zbog svojih pročišćavajućih i ublažavajućih svojstava, kao i da je on u ovaj vid ishrane uključio praščiće i jariće (ponegdje se dodaju i pijetlo-

Sve ono što su oni određivali u pogledu toga što se mora ili što se ne smije činiti smjeralo je prema druženju s božanstvom, $i$ to je bio njihov princip; ne samo da im je sav život bio uređen spram poslušnosti koja se duguje bogu, nego je i smisao te filozofije bio taj da smiješno postupaju ljudi koji dobro traže od nekuda druguda umjesto od bogova. ${ }^{16}$ vi). Ovo nisu samo zanimljivi detalji koji možda razbijaju ili bi trebali razbiti monotoniju izlaganja u ovom radu. Aristoksen je, po autorovu mišljenju, želio pokazati onima koji su u njegovu vremenu (4. st. pr. n. e.) prenaglašavali suzdržavanje od mesne ishrane da su, ako tako može reći, postali veći pitagorejci od samog Pitagore. Sam Aristoksen imao je prijatelje među učenim pitagorejcima koji su vjerojatno bili relaksirali ili relativizirali one elemente doktrine koji im nisu izgledali vrlo smislenima. Napuštanje drevnih propisa sigurno nije moglo proći bez reakcije odnosno otpora najrevnijih pitagorejaca te su učeni pitagorejci bili optuživani, modernom terminologijom rečeno, za reviziju tj. „herezu“ izvornog pitagorizma. ${ }^{12}$

Prema drugim svjedočanstvima Aristoksena (DL, VIII, 20), Pitagora je navodno dozvoljavao da se jedu sva živa stvorenja osim volova koji oru i ovnova. Ova tvrdnja, kad se razmisli, manje upućuje na srodstvo ljudi, barem s volovima, a više govori o pragmatičnim razlozima nejedenja radnih životinja. ${ }^{13}$

Stavljajući ljude u isti rang sa životinjama, Pitagora je zahtijevao da se one smatraju srodnicima i prijateljima i da im se ni u kojoj prilici ne nanosi šteta. Mislio je da se time potiče mirotvorstvo, jer ako se ljudi počnu groziti ubojstva životinja, kao nečeg nezakonitog i neprirodnog, neće ni ubojstvo čovjeka smatrati časnim činom pa posljedično neće niti ratovati. Ovu ,indirektnu” dužnost što se tiče životinja potom su prepoznali Kliment Aleksandrijski, Majmonid, Toma Akvinski, Kant i neki moderni filozofi, a i danas se upotrebljava kao argument zašto ne treba vršiti eksperimente na životinjama. Razlog je kasnija moguća dehumanizacija samog čovjeka. ${ }^{14}$

Duša je prema Pitagori bila besmrtna ( $\dot{\alpha} \theta \alpha \dot{v} v \alpha \tau o \varsigma),{ }^{15}$ a to je podrazumijevalo znatno više od običnog, odnosno pukog preživljavanja. Moglo bi se reći da je riječ o svo-

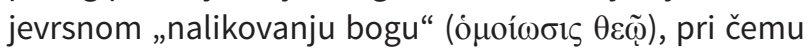
put do spasenja nije pronalazio u objavi ili odgovarajućem setu zabrana, već u filozofiji. Interesantan i referentan uvid u pitagorejsko učenje u ovom smislu dao je Aristoksen (DK58D2) ]

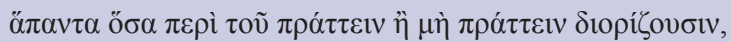

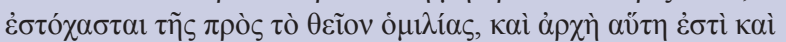

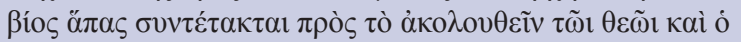

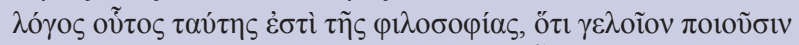

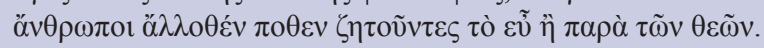


Ova asocijacija i relacija duše prema onom božanskom primjereno demonstrira vezu religiozne i filozofske odnosno znanstvene strane pitagorejskog učenja, iako je od ranih dana bilo takvih intencija, čineći ih licem i naličjem jednog jedinstvenog „sustava“. ${ }^{17}$

Za Pitagoru katarza i spas duše, kao što je navedeno, nisu ovisili jednostavno, kao u misterijskim kultovima, o odgovarajućoj inicijaciji i ritualnoj čistoći, nego o filozofiji. S pravom je J. Burnet napisao da je filozofija u Joniji značila nešto kao „radoznalost“, a da je riječ $\varphi \imath \lambda o \sigma o \varphi^{\prime} \alpha^{18}$ imala znatno složenije značenje gdje se god može pronaći trag Pitagorina utjecaja. Sama philosophia bila je „očišćenje“ i način bježanja od „kotača“ ${ }_{19}^{19}$ što predstavlja karakteristiku najbolje grčke misli. ${ }^{20}$ Filozofija je zapravo tada slično kao i danas značila upotrebu moći davanja dokaza (logon didonai) motrenja radi postizanja znanja.

Načelo kosmosa koje sjedinjuje filozofa s božanskim ilustrira mjesto iz Platonove Države (500b-d) $]$

Onaj ko je svoj duh zaista upravio prema onome što stvarno jest, nema vremena, o Adeimante, da spušta svoj pogled na ljudske stvari, da se bori sa njima i da se ispunjava zavišću i mržnjom, nego gleda i posmatra uređene stvari koje uvek ostaju iste, u kojima nema međusobnog pričinjavanja niti podnošenja nepravde, nego u kojima vladaju samo red i razložnost (logos).

To on podražava i sa tim se izjednačuje što najviše može...

Filozof, dakle, koji se bavi onim što je božansko i uređeno, postaje i sam uređen i božanski, ukoliko je to čoveku moguće. ${ }^{21}$
Osim dovođenja u blisku vezu pitagorizma i atomizma na početku ovog pasusa, Stagiranin pri kraju pasusa pod „onima koji tvrde“ da je duša samopokrećuće načelo aludira na platonovce. ${ }^{25} \mathrm{U}$ nastavku odlomka (De An. 404a21-25) njegova se kritika konkretizira: platonovci nisu vidjeli da postoji išta što pokreće a da se i samo ne kreće. Prvobitno načelo, kako su ga Grci shvaćali i znatno prije Platona i njegovih sljedbenika, razumijevalo se kao vječno i stoga nužno neuzrokovano ili samouzrokovano te bez jasno razgraničenog, aristotelovski rečeno, causa materialisa i causa efficiensa. Odgovor na pitanje što je to samouzrokovano ili samopokrećuće sve otprilike od 6. st. p. n. e. gotovo je uvijek bio isti: duša ili život $(\psi v \chi \eta ́) .{ }^{26}$

Za rane predsokratovce osnovno bivstvo na je neki način bilo oživljeno i odnosilo se prema vidljivom tjelesnom svijetu kao duša prema ljudskom tijelu. ${ }^{27}$ Aristotel u Met. 985b23-26 piše da su pitagorejci odgajani i obra-

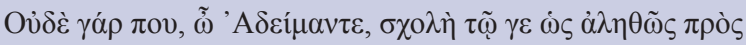

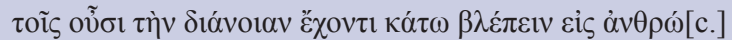

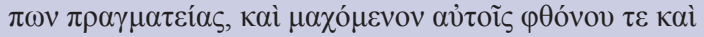

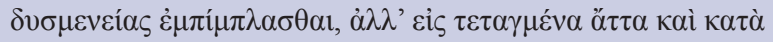

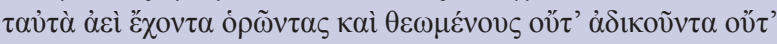

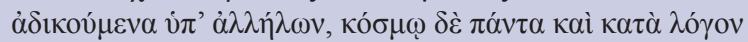

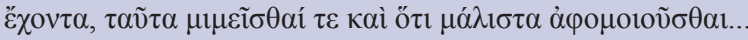

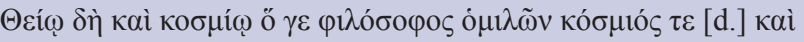

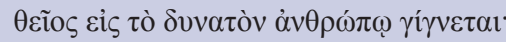

Kasniji se komentatori slažu da je numeričko objašnjenje univerzuma generalizacija koja je apstrahirana iz izvanrednog Pitagorina otkrića da $\dot{\alpha} \rho \mu o v i ́ \alpha,{ }^{22}$ koju je izjednačio s brojem, ima glazbenu konotaciju, što je poznato iz Stagiraninova objašnjenja „harmonije sfera”, i može se pretpostaviti iz Platonova iskaza (Rep. 531a) da „traže numeričke relacije u zvučnom skladu”. 23

Najbolje stanje, po Pitagori, ono je u kojem su oprečne kvalitete toliko izmiješane, uz puno poštovanje zakona proporcije, da su njihove opozicije neutralizirane do te mjere da tvore eufoniju u glazbi, zdravlje u tijelu i kosmos tj. red i ljepotu u univerzumu kao cjelini.

Aristotel zatim navodi pitagorejsko određenje duše ( $D e$ An. 404a17-21) ]

Neki od njih su ustvrdili da je duša ta prašina u vazduhu, a drugi da je ona to što ovu pokreće. A što se te /prašine/ tiče, za nju je rečeno da je | očigledno neprekidno u pokretu, pa čak i da nema nimalo vetra. Na isto se svode i oni koji tvrde da je duša to što pokreće samo sebe. ${ }^{24}$ zovani u duhu matematike, kao i da su smatrali da su njezina načela bila i načela svih bića. lako su pitagorejci najčešće opisivali strukturalnu shemu stvari, njihovo je uvjerenje bilo da su istovremeno ocrtavali i tvarnu prirodu istih tih stvari. Italskim filozofima bilo je moguće da govore o odnosu stvari i brojeva, a da pritom brojeve, bez ikakvih problema u vlastitom rasuđivanju, tretiraju i kao aritmetičke jedinice i kao geometrijske točke i kao fizikalne atome. Proces nastajanja zato su mogli objašnjavati na sljedeći način: iz ograničenog i neograničenog, neparnog i parnog nastaju brojevi, iz brojeva nastaju geometrijske figure, a od geometrijskih figura nastaju fizikalni objekti. ${ }^{28}$

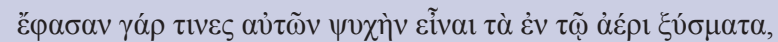

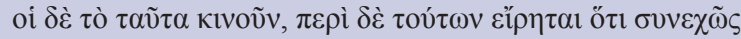

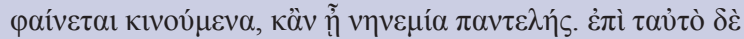

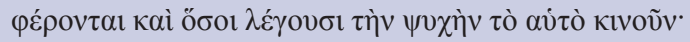


Stagiranin je potom smatrao da je duša za pitagorejce stanje ili uređenje brojeva, o čemu izvještava u petom poglavlju prve knjige Metafizike (985b26-31) ]

A kako su brojevi tu po prirodi prvi, a njima se činilo da kod njih opažaju mnoge sličnosti s onim što jest ili što postaje, pre nego kod vatre, zemlje, $i$ vode, zato što je takvo i takvo svojstvo brojeva pravednost, lovakvo duša, a drugo um, povoljan čas, $i$ ukratko podjednako i sve ostalo. ${ }^{29}$ nja na spomenute numeričke opservacije ${ }^{31}$ otkrivanje snažnog utjecaja osobenog pitagorejskog učenja na ne(u)obič(aje)ni matematički pristup praktičkoj filozo-
Kada Aristotel u Met. 985b26 kaže da su brojevi „po prirodi prvi” ( $\varphi v ́ \sigma \varepsilon 1 \pi \rho \tilde{\omega} \tau o 1)$, to znači da su najjednostavniji od matematičkih stvari. Stagiranin u Met. 985b29 govori da je pitagorejcima nekakvo „svojstvo (kurziv Ž. Kaluđerović) brojeva" pravednost, neko drugo svojstvo duša ili um, a neko treće pak „povoljan čas“. U tekstu je upotrijebljena teško prevodiva grčka višeznačnica $\pi \dot{\alpha} \theta$ os, za koju je na ovom mjestu najbolje zadržati prijevod „svojstvo", jer ako se pogleda npr. odlomak iz Met. 1004b1012 , vidjet će se da su „neparnost, parnost, razmjernost,

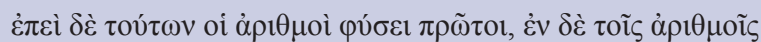

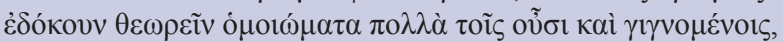

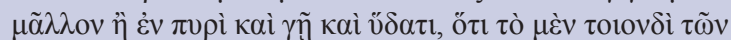

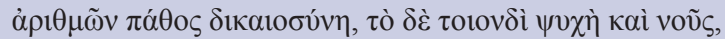

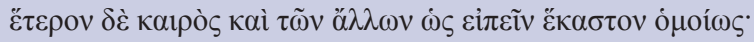

Mudri ljudi, moj Kalikle, tvrde da su prijateljstva, poštovanje reda, zatim umerenost i pravednost one snage koje povezuju nebo i zemlju, bogove i ljude, te zato vasionu oko nas nazivaju kosmosom, što znači red, a ne razuzdanost i nered, moj dragoviću. A ti, kao što vidim, ne pridaješ nikakve važnosti svemu tome, i pored toga što si filozof, i zato ti je ostalo nepoznato da geometrijska jednakost ima veliku moć među bogovima i među ljudima. Ti misliš da je najvažnije to da se ima više, jer zanemaruješ geometriju. ${ }^{32}$ fiji koji se može pronaći kod Platona. U raspravi koja se vodi u dijalogu Gorgija Sokrat je minuciozno objašnjavao Kaliklu da se vrlina svake stvari sastoji u redu i u skladnosti koja proizlazi iz reda. Posljedično tome, i duša koja ima u sebi svoju vlastitu skladnost bolja je od one duše koja tu skladnost nema. Duša koja posjeduje takvu skladnost razborita je, harmonična i umjerena, a umjerena je i pravedna duša, konačno, dobra.

Sokrat se potom obraća Kaliklu (Gorg. 507e-508a) I

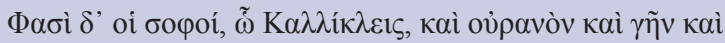

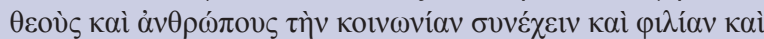

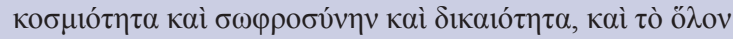

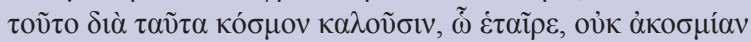

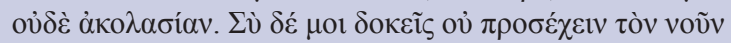

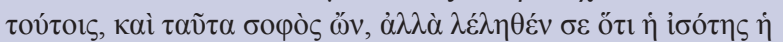

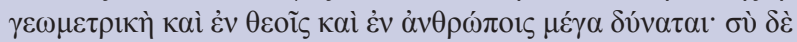

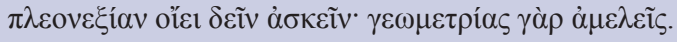

jednakost, nadmašivanje, zaostajanje" navedeni kao

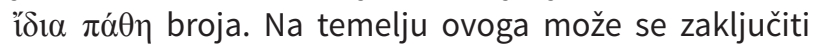
da su pitagorejci identificirali dikaiosyne, psyche, nous i kairos s određenim „svojstvom” broja kao što je neparnost ili kvadratnost.

Aristotelovo spominjanje duše i uma kod pitagorejaca kao svojstva brojeva, da se zbog prirode istraživanja u ovom radu zadržimo na njima, može se razumjeti kao

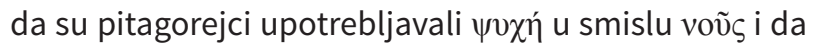
su oba pojma bila predstavljena istim brojem, jedinicom. Nešto oprezniji pristup bio bi da je na osnovi Stagiraninova navoda jedino moguće reći da su duša i um bili predstavljeni istim brojem, a da je taj broj najvjerojatnije broj 1. Postoje, istina, i bilješke koje sugeriraju da je duša bila predstavljena brojem 2 (a um brojem 1), imajući u vidu da se kreće od premisa ka konkluziji, brojem 4, brojem 6 ili čak brojem 216. ${ }^{30}$

Neki povjesničari filozofije smatraju da je možda najveća dobrobit od obraćanja pažnje i usmjeravanja mišlje-
Platonovo spominjanje „mudrih ljudi” (oi бo甲oí) na početku pasusa vjerojatno se odnosi na pitagorejce $i$ Empedokla. ${ }^{33}$ Kada Sokrat kaže da ti ljudi cjelinu svega nazivaju kosmosom, „što znači red”, samo je izrazio jedno od reprezentativnih značenja grčke imenice muškog

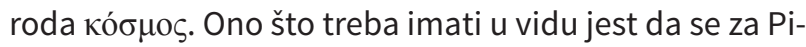
tagoru tradicionalno tvrdilo da je bio prvi koji je upotrijebio ime kosmos za svijet, u znak priznanja za red koji manifestira.

Iz Gorgije se može uočiti da matematički i „polumatematički" primjeri, premda ne toliko kompleksni kao u Menonu, također nagovještavaju pitagorejske elemente kao uzor. U Gorg. 465b Sokrat kaže da će zbog sažetosti govoriti ,jezikom matematičara" i odmah potom nastavlja govoriti o dvostrukoj proporciji tipa $a: b:: c: d$ i e:f::g:h. Još izrazitiji primjer utjecaja pitagorizma iznosi se u Gorg. 503e-504a, gdje se kaže da je cilj slikara, građevinara i brodograditelja da strogo određeno (taxis) raspolažu pojedinim elementima u svojem radu, pode- 
šavajući ih tako da se slože jedni s drugima dok sve ne bude sjedinjeno u lijepu i harmoničnu cjelinu (kosmos). Slično i liječnici i učitelji gimnastike tijelo dovode u red i odgovarajuću skladnost. Ovo naglašavanje važnosti kosmosa, koje je usko povezano s kozmičkom važnošću matematičkih zakona, nesumnjivo je pitagorejskog porekla. ${ }^{34}$

Platonov interes za pitagorejsku tradiciju u Gorgiji vidljiv je i na mjestu gdje Sokrat citira Euripida (,Ko zna nije li život smrt i nije li smrt život?" (Gorg. 492e), kao i kada se tijelo ( $\sigma \tilde{\omega} \mu \alpha ́)$ dovodi u vezu s grobnicom ( $\sigma \tilde{\mu} \mu \alpha)$ duše (Gorg. 493a). ${ }^{35}$ Kada u nastavku pasusa (Gorg. 493a-c)

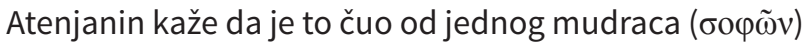
i potom dovede u vezu požudni „dio“ duše s probušenom bačvom koja se ne može napuniti, ima potrebu dodatno pojasniti da je tu priču izmislio neki duhoviti čovjek „vjerojatno sa Sicilije ili iz Italije“, aludirajući na pitagorejce, a možda i na „pitagorejca“ Empedokla.

Na tragu W. K. C. Guthrieja može se zaključiti da su postojale dvije suvremene predodžbe duše: Jedna je psyche, koja iščezava u trenutku smrti i koju medicinski pisci, uključujući i neke skeptičke i „,heretičke“ pitagorejce, racionaliziraju u harmoniju fizičkih opreka koje sačinjavaju tijelo. ${ }^{36}$ Drugi je više tajnoviti daimon ${ }^{37}$ u čovjeku, koji je besmrtan trpeći palingenesiju (transmigraciju u Guthriejevoj verziji) kroz mnoga tijela, ali je u svojem čistom bivstvu božanski. Obje su predodžbe duše preživjele, rame uz rame, u generalnom toku religiozne misli, kao što su i obje opstale u neobičnoj kombinaciji matematičke filozofije i religioznog misticizma koja je stvorila pitagorizam. ${ }^{38}$

\section{Literatura:}

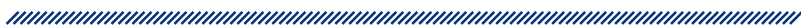

1. Herodot u svojoj Povijesti (II, 123), uz određeni oprez, prenosi informaciju da su navodno Egipćani prvi zagovarali palingenesiju. Zanimljiva je njegova bilješka pri kraju pasusa da su ovo mišljenje odnosno shvaćanje „prihvatili i pojedini Heleni“, neki ranije, a neki kasnije, i da su se ponašali kao da su ga sami izmislili. Herodot piše da, iako što su mu poznata njihova imena (Pitagora, Empedoklo?), ipak ih neće spominjati i navoditi. Vidi: Herodot (2009). Istorija. Beograd: Dereta, str. 102. Huffman pak smatra da je, osim verzije o Egipćanima, moguće i da je sam Pitagora tvorac doktrine o seobi duše, kao i da je, što je po njemu vjerojatnije, njezino porijeklo iz Indije. Huffman, C. A., „The Pythagorean tradition”, p. 70, u: A. A. Long (ed.) (1999). The Cambridge Companion to EARLY GREEK PHILOSOPHY. Cambridge: Cambridge University Press.

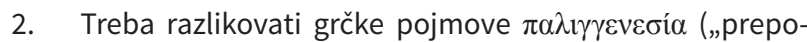
rod”, „obnavljanje duše”) i $\mu \varepsilon \tau \varepsilon \mu \psi v ́ \chi \omega \sigma ı$ (,prelazak duše iz tijela u tijelo") (pojedini novoplatonisti i kršćanski apologeti upotrebljavaju i pojam $\mu \varepsilon \tau \varepsilon v \sigma \omega \mu \alpha ́ \tau \omega \sigma ı \varsigma$ („ulazak (duše) u drugo tijelo“). Neprecizniji i, nažalost, češće

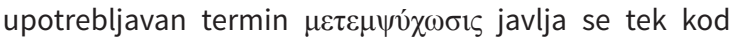
poznijih autora. Ovaj je izraz neprecizniji jer sugerira da je u pitanju vjerovanje koje govori o preegzistenciji ili samostalnoj egzistenciji duša, dok kod izraza $\pi \alpha \lambda \iota \gamma \gamma \varepsilon v \varepsilon \sigma i ́ \alpha$ to nije slučaj. Izvorno pitagorizam, naime, predmnijeva da se duša, u obliku života, seli iz tijela u tijelo. Tijelo, naravno, mora da umrijeti da bi duša izašla iz njega i na neki misteriozan način produžila svoju egzistenciju u novom organizmu. Vjerovalo se, dakle, da smrt nekog čovjeka označava u isti mah rađanje nekog drugog živog bića, da, konačno, duša nigdje i nikada ne postoji sama za sebe izvan tijela.

3. Prev. J. Kaštelan. Diels, H., (1983). Predsokratovci fragmenti I. Zagreb: Naprijed, str. 132, B7. Njem. izd. Diels, H., Kranz, W., (1985). Die Fragmente der Vorsokratiker I. Zürich: Weidmann, s. 131, B7.

4. Sudeći prema bilješkama Diogena Laertija (VIII, 4), odnosno pričama Heraklida s Ponta, Pitagora je mogao i u životu i u smrti sačuvati sjećanje na sve što je doživio. U životu se mogao sjetiti svega, a poslije smrti bi sačuvao isto pamćenje.

5. Da duša na neki način nastavlja život nakon smrti i da palingenesia uključuje nagrade i kazne za prethodno učinjeno vidljivo je i iz bilješke lona s Hija (DK36B4).

6. Detaljnije vidi u: Guthrie, W. K. C. (1962). A History of Greek Philosophy I. Cambridge: Cambridge University Press, p. 202.

7. Bob nije sinoniman odnosno identičan s grahom (lat. Phaseolus vulgaris), koji je porijeklom iz Južne Amerike i u Europi se prvi put spominje tek otprilike 1542. godine.

8. Prev. M. Tasić. Jamblih (2012). Pitagorin život. Beograd: 
DERETA, str. 69. Pitagora je zabranjivao i da se jede sljez (lat. Malvaceae), s obrazloženjem da je ova biljka prvi glasnik i svjedočanstvo simpatije onog nebeskog prema onom zemaljskom.

9. Učenje o palingenesiji jedno je od rijetkih bitnih pitagorejskih stavova za koje Stagiranin nije naš najraniji izvor. Njegovo referiranje o spomenutoj temi (De An. 407b2026) ipak se s dužnom pažnjom uzimalo u obzir čak i kada je bilo izrečeno u negativnom kontekstu. Aristotelova je teza da svako tijelo mora biti povezano sa sebi svojstvenim oblikom i likom te da svaki živi organizam mora biti povezan sa sebi svojstvenom dušom. Stagiranin je mogao imati na umu Ksenofanove riječi iz spominjanog 7. fragmenta (DK21B7), kada piše „kao da je kao u pitagorejskim basmama moguće da bilo koja duša uđe u bilo koje telo" (De An. 407b21-23), i smatrati da se u tijelo psa ne može smjestiti duša čovjeka, ali je vjerojatnije da je njegovo učenje načelnijeg karaktera.

10. Uvjerenje ili svojevrstan osjećaj da se treba kloniti hrane životinjskog porijekla, ali ne i sve koja je biljnog porijekla, može se dovesti u vezu i s drevnim otklonom i strahom od skrnavljenja srodnom krvlju (koje najbolje detektiraju dvije imenice srednjeg roda u klasičnom grčkom jeziku ơyos („(krvna) krivnja“, „grijeh“, „ono što se mora okajati“) i $\mu i ́ \alpha \sigma \mu \alpha$ („skrnavljenje“, „grozota“), koji je Pitagora vjerojatno naslijedio od svojih nefilozofskih preteča. Empedoklo je vlastiti otpor takvim praksama pokušao također filozofski utemeljiti, premda se u njegovom 139. fragmentu (DK31B139) priziva još starije doba.

11. Empedoklo je, naprimjer, mislio (DK31B137) da transmigracija podrazumijeva da ljudi doslovno ubijaju svoje srodnike, odnosno da čovjek koji jede meso može pojesti svojeg sina, kao i sin oca, ili da djeca mogu pojesti svoju majku zato što su izmijenili obličje.

12. Detaljnije vidi u: Guthrie, W. K. C. (1962). A History of Greek Philosophy I. Cambridge: Cambridge University Press, pp. 182-195; Burnet, J. (1962). Early Greek Philosophy. Cleveland and New York: The World Publishing Company, pp. 93-96; Pavlović, B. (1997). Presokratska misao. Beograd: П $\Lambda$ AT $\Omega$, str. 101-103; Mattéi, J. F. (2009). Pitagora i pitagorovci. Zagreb: Jesenski i Turk, str. 19-28.

13. S druge strane, Pitagora je vjerovao da hrana pomaže obrazovanju ljudi, ako je kvalitetna i redovita, pa je odobravao da se jede ono što dovodi tijelo u zdravo i smireno stanje. Bio je također uvjeren da odgovarajuća hrana pogoduje umijeću proricanja, čistoći i neporočnosti duše, odnosno razboritosti i vrlini.

14. Porfirije u trećoj knjizi spisa O uzdržavanju od oduševlje-

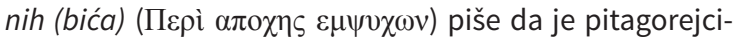
ma blagost prema životinjama bila vježba filantropije i sućuti. Porphyry, On Abstinence from Animal Food, 3.20, p. 116. Preuzeto s internetske adrese: https://books. google.rs/books?id=pu5hAAAAcAAJ\&printsec=frontco ver\&dq=porphyry+on+abstinence+from+animal+food +pdf\&hl=en\&sa=X\&ved=0ahUKEwjWkejdnr_TAhVBtxoK HTY1BxIQ6AEIJjAB\#v=onepage\&q\&f=false, pristupljeno
25. travnja 2017. Određeni segmenti ovog dijela članka preuzeti su, uz znatne korekcije, iz: Kaluđerović, Ž., Jašić, O., „Pitagorejska i arapska recepcija ne-ljudskih živih bića”. Nova prisutnost. 2015. 13. 1.: 25-33.

15. Porfirije (V. Pyth. 19) eksplicitno navodi da je najprije postalo općepoznato Pitagorino kazivanje da je duša be-

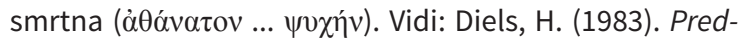
sokratovci fragmenti I. Zagreb: Naprijed, str. 98, 8a. Kahn smatra da je poimanje duše kao besmrtne, posljedično i potencijalno božanske, jedna od dvije grupe ideja (druga predstavlja pokušaj razumijevanja i objašnjenja prirode stvari matematičkom terminologijom) koje omogućavaju trajnu vitalnost pitagorejske tradicije. Kahn, C. H. (2001). Pythagoras and the Pythagoreans. Indianapolis/ Cambridge: Hackett Publishing Company, Inc., p. 4.

16. Prev. A. S. Kalenić. Diels, H. (1983). Predsokratovci fragmenti I. Zagreb: Naprijed, str. 423, D2. Njem. izd. Diels, H., Kranz, W. (1985). Die Fragmente der Vorsokratiker I. Zürich: Weidmann, s. 468, D2.

17. Vidi: Guthrie, W. K. C. (1962). A History of Greek Philosophy I. Cambridge: Cambridge University Press, pp. 198-200.

18. Prema Diogenu Laertiju, on je i tvorac ovog neologizma (I, 12). Vidi: Laertije, D. (1973). Životi i mišljenja istaknutih filozofa. Beograd: BIGZ, str. 4.

19. Ta ideja je potom na adekvatan način izložena u Platonovu Fedonu.

20. Burnet, J. (1962). Early Greek Philosophy, Cleveland and New York: The World Publishing Company, p. 83.

21. Prev. A. Vilhar, B. Pavlović. Platon (1993). Država. Beograd: BIGZ, str. 191-192, 500b-d. Original Države preuzet je iz: Platon (1990). DER STAAT. Werke: in 8 Bd.; griech. u. dt., vierter band, Hrsg. von G. Eigler, Darmstadt, s. 516-517, 500b-d.

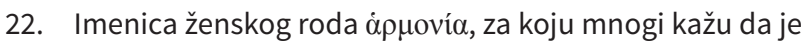
ključna riječ pitagorizma, ima sljedeća značenja: „spajanje”, „slaganje”; „veza”, „ugovor”; „sklad”, „suglasje”, „harmonija”; ime Zeusove kćeri koja se zove Apuovía. Harmonia još može značiti „ljestvica”, pa i „oktava”. Za harmoniju se u jednoj od acusmata (DK58C4) kaže da je

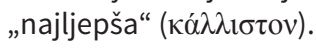

23. Ovakvu tezu podržavaju, recimo, Barnet, Taylor i Cornford.

24. Prev. S. Blagojević. Aristotel (2012). O duši, u: O duši. Parva naturalia. Beograd: PAIDEIA, str. 15-16, 404a 17-21. U pitagorejskoj kozmogoniji duša također mora biti jedina početna instancija, kao što je za miletske mislioce jedno arche bilo božansko načelo u njihovu svijetu.

25. Vidi: Phaedr. 245c-246a; Nom. 895e-896a, Nom. 966e.

26. Ova relativno česta srodnost pa i poistovjećivanje duše i života ne znači da pitagorejci nisu bili uvjereni da je duša, premda jest harmonija, također, kao što je nekoliko puta navedeno u ovom radu, besmrtna. Besmrtnost duše, štoviše, ono je o čemu ovisi da duša bude harmonija, a pod njom (harmonijom) ovdje se posebno misli na skladnost kozmičkog odnosno numeričkog tipa. Činjenicu besmrtnosti duše utvrđuje i E. Rohde, dodajući da je 
duša besmrtna zato što je vječna. Rode, E. (1991). PSYC$H E$. Sremski Karlovci. Novi Sad: Izd. knjiž. Z. Stojanovića, str. 289. Vidi i: DK44A23, DK44B14, DK44B22; Phaed. 81d, Phaed. 86b-c; De An. 405a29-405b1, De An. 407b27-32, De An. 408a5-9; Pol. 340b18-19.

27. Vidi: Jaeger, W. (1967). The Theology of the Early Greek Philosophers. Oxford: Oxford University Press, p. 79.

28. Vidi i: Kaluđerović, Ž. (2017). Rana grčka filozofija. Zenica: Hijatus. str. 65-76.

29. Prev. S. U. Blagojević. Aristotel (2007). Metafizika. Beograd: PAIDEIA, str. 18, 985b26-31. Usporediti i Platonove bilješke: Rep. 525d, Rep. 527b, Rep. 529d; Tim. 35b.

30. U DK14.8 pronalazi se moguće objašnjenje za ovaj broj. Tamo se, naime, navodi da je Pitagora: „Metempsihoze koje su mu se izvršile prošao u razmacima od po 216 godina: poslije toliko se dakle godina Pitagora iznova rodio i opet došao u život."Prev. A. S. Kalenić. Diels, H. (1983). Predsokratovci fragmenti I. Zagreb: Naprijed, str. 96, 8. njem. izd. Diels, H., Kranz, W. (1985). Die Fragmente der Vorsokratiker I. Zürich: Weidmann, s. 99, 8.

31. U pseudo-Aleksandrovom komentaru jednog Aristotelova odlomka (Met. 1092b8-13), može se uočiti kako pitagorejac Eurit (koji je živio na početku 4. st. p. n. e. i bio je Filolajev učenik) izlaže zanimljivu kombinaciju mozaičnog predstavljanja likova s pomoću raznobojnih kamenčića i pitagorejskog numeričkog simbolizma (DK45.3). Vidi: Diels, H. (1983). Predsokratovci fragmenti I. Zagreb: Naprijed, str. 366, 3.

32. Prev. A. Vilhar. Platon (1968). Gorgija, u: Protagora. Gorgija. Beograd: Kultura, str. 166, 507e-508a. Original Gorgije preuzet je iz: Platon (1988). DES SOKRATES APOLOGIE. KRITON. EUTHYDEMOS. MENEXENOS. GORGIAS. MENON. Werke: in 8 Bd.; griech. u. dt., zweiter band, Hrsg. von G. Eigler, Darmstadt, s. 450, 507e-508a. Usporediti: Rep.431e-432a, Rep.443d.

33. Pasus iz Magna Moralie (1182a11-14), vjerojatno djelo nekog ranog sljedbenika Aristotela, ali koje u osnovi izražava njegova gledišta, može dodatno potkrijepiti tezu da su бoøoí koji se spominju na ovom mjestu u Gorgiji ustvari pitagorejci.

34. Detaljnije vidi u autorovoj knjizi. Kaluđerović, Ž. (2015). Dike i dikaiosyne. Skopje (Makedonija): Magnasken, str. 131-133, 199-200.

35. Slično i u Crat. 400c.

36. Autor je u ovom istraživanju ovlaš spominjao tzv. pretežno fizikalna objašnjenja duše, poput onih koja kao Simija i Kebet u Fedonu (86b) dušu tretiraju kao smjesu

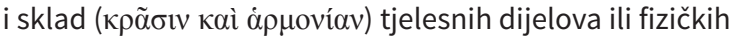
suprotnosti (a samim time i kao smrtnu i propadljivu), ili onih koji dušu u određenoj mjeri poistovjećuju s eterom ( $\alpha i \theta \varepsilon ́ p o \varsigma)$ tj. onih koji navode da je duša neka praši-

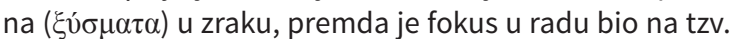
religioznim i filozofskim poimanjima duše.

37. Guthrie je u svojoj knjizi napisao termin daimon koji je Empedoklo upotrebljavao kao ekvivalent za dušu. Nazivajući dušu daimonom prije nego psycheom, Empedoklo je vjerojatno želio naglasiti božansku prirodu čovjeka.

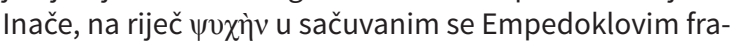
gmentima nailazi samo jednom (DK31B138).

38. Ovaj pasus predstavlja parafrazu tj. prijenos Guthrieijevih riječi iz odlomka njegove knjige Povijest grčke filozofije I, poglavlje o Pitagori i pitagorejcima, koje je on imenovao kao „Priroda duše“. Guthrie, W. K. C. (1962). A History of Greek Philosophy I. Cambridge: Cambridge University Press, p. 319. 


\section{SOUTHERN ITALIAN DOCTRINE OF THE SOUL}

\section{1 Željko Kaluđerović}

1 Department of Philosophy, University of Novi Sad, Faculty of Philosophy, Novi Sad, Serbia

Summary: The paper investigates directly and indirectly preserved views of Pythagoras and Pythagoreans who, according to the author, represent the antecedents of deviations from the mainstream Western philosophy and anticipate the majority of later modalities of non-anthropocentric approaches. Fragments of italic thinkers, in other words can serve almost as guidelines for today highly actual (bio)ethical requirements for a new and different resolution of the relation between humans and so called non-human living beings. The Pythagorean idea that all forms of life are kindred brought into connection not only humans with animals and plants, but also indicated that human soul, however only after purification, can achieve melding with eternal and divine soul, to which it belongs by its own nature. The link and analogy that may be established between a man and universe is referred to in Aristotle's statement that, according to Pythagoreans it is possible for any soul to enter any body. This kinship of all varieties of life, eventually, was a necessary prerequisite for the Pythagorean doctrine on immortality and the transmigration of souls. Xenophanes reports about palingenesia by a well known statement that once when Pythagoras saw some people beating a dog and advised them to stop, since in the yelping of the dog he recognized the soul of his friend. From Colophonian fragment (DK21B7) it is evident why kinship of all beings which is associated with the doctrine of the transmigration of souls is at the basis of the Pythagorean ban on the eating of animal flesh. Pythagoras' recognition of his friend's soul embodied in a dog illustrates the transfer of personal identity on the psyche, which means that a personality somehow survives in the migrations of the soul and that there is a continuity of identity. The conclusion that can be derived, at least implicitly, is that ensouled beings, therefore animals, but also certain plants, in a sense, are conscious beings.

Keywords: Pythagoras and Pythagoreans, non-anthropocentrism, kinship, life, soul, doctrine, immortality, palingenesia 